九州大学学術情報リポジトリ

Kyushu University Institutional Repository

Reverse Osmosis Separation of Some Monoamino Monocarboxylic Acids in Aqueous Solutions Using Cellulose Acetate Membrane

Tozawa, Osami

Laboratory of Food Technology. Faculty of Agriculture, Kyushu University

Nomura, Danj i

Laboratory of Food Technology. Faculty of Agriculture, Kyushu University

https://doi.org/10.5109/23721

出版情報: 九州大学大学院農学研究院紀要. 25 (2/3)，pp.73-90，1980-11. Kyushu University バージョン：

権利関係 : 
J. Fac. Agr., Kyushu Univ., 25 (2 • 3), 73-90 (1980)

\title{
Reverse Osmosis Separation of Some Monoamino Monocarboxylic Acids in Aqueous Solutions Using Cellulose Acetate Membrane
}

\author{
Osami Tozawa and Danji Nomura \\ Laboratory of Food Technology. Faculty of Agriculture, \\ Kyushu University 46-09, Fukuoka 812
}

(Received June 2. 1980)

\begin{abstract}
The reverse osmosis separation of some monoamino monocarboxylic acids (1.0x $10^{-3} \mathrm{~mol} / l$ ) in single aqueous solutions was carried out by batch cell under an operating pressure of $20 \mathrm{Kg} / \mathrm{cm}^{2} \cdot \mathrm{G}$ at a temperature of $30^{\circ} \mathrm{C}$. using DDS-cellulose acetate membrane. Taft's polar parameter $\left(\Sigma \sigma^{*}\right)$, Taft's steric parameter $\left(\Sigma E_{s}\right)$ and nonpolar parameter $\left(\Sigma S^{*}\right)$ governing reverse osmosis separations of nonionized polar aliphatic and alicyclic organic compounds could be applied to amino acids whose substituents are composed of hydrocarbon, such as aliphatic amino acids and part of aromatic amino acids. These three parameters $\left(\Sigma \sigma^{*}, \Sigma E_{s}\right.$, $\left.\Sigma S^{*}\right)$ were correlated with polarity of covalent bond, molecular weight of substituent, and interaction energy of London-van der Waals dispersion force, respectively. As a result, these characteristic parameters were also applied to sulfurcontaining amino acids, aromatic amino acids, and hydroxy amino acids. The calculated values of rejection of amino acids based on these parameters agreed with observed values approximately. Also, the separation of monoamino monocarboxylic acids in binary aqueous solution system containing L-alanine $\left(1.0 \times 10^{-3}\right.$ mol $/ l$ ) was carried out by reverse osmosis under the same operating conditions. As a result, preferential permeability of L-alanine was governed with Taft's polar parameter of added amino acids in the concentration range of added amino acids $\left(<1.0 \times 10^{-3} \mathrm{~mol} / \mathrm{l}\right)$, in which the formation of adsorbed layer of added amino acids on the surface of membrane might be taken place.
\end{abstract}

\section{INTRODUCTION}

The asymmetric cellulose acetate membranes which were developed by Loeb and Sourirajan for the purpose of desalination about two decades ago are still industrially important ones and have been a model of synthetic polymer membranes up to date. The studies of mechanism for reverse osmosis have been done extensively regarding the separation of inorganic salts. As a result, various kinds of theory are proposed as follows; solution-diffusion mechanism (Lonsdale et al., 1965, 1971), concept of pore (Glueckauf, 1967; Bean, 1969) and phenomenological treatment (Kedem and Katchalsky, 1958) etc. Also, regarding the separation mechanism of organic compounds, Matsuura et al. $(1976,1977)$ have analyzed the permeation of nonionized polar aliphatic and alicyclic organic compounds in single solution system, and proposed the equation of permeation which was based on a porosity of membrane and molecular 
parameters, such as hydrogen bonding action, hydrophobic action and steric effect. But there is little systematic researches concerning the separation of ionic organic compounds by reverse osmosis. On the other hand, amino acids are amphoteric electrolytes existing as zwitter ions in aqueous solutions. Amino acids are present in many biochemical systems. It is very interesting that they are found in the primeval sea as a first formed life relative organic substance, therefore, an investigation on reverse osmosis separation of amino acids using cellulose acetate membranes might make a contribution to not only a clarification of permeation of ionic organic compounds and an application of the membrane process to biochemical and chemical industry, life science, etc. but also a future development of polymer membranes.

The purpose of this work was to study the criterion for the separation of monoamino monocarboxylic acids in single and binary aqueous solution systems with cellulose acetate membranes by reverse osmosis as a fundamental.

\section{MATERIALS AND METHODS}

Monoamino monocarboxylic acids of aliphatic, hydroxy-substituted, sulfurcontaining, and aromatic types were reagent chemicals and cellulose acetate membranes used were DDS-600, 800, 870 and 880 . They were supplied by De Danske Sukkerfabrikker.

The concentration of amino acid in single aqueous solution was measured by a spectrophotometer, Hitachi Model 100-30. Amino acids in binary aqueous solution were analyzed with paper chromatography or thin-layer chromatography, and determined by the use of a densitometer, DMU-33C (Toyo-Kagaku Sangyo, Inc.). The concentration of sodium chloride was measured by a conductivity bridge, CD-35M II (MS, Inc.).

A batch of stirred cell (Bio Engineering RO-3) was used in all the experiments. The feed volume was $200 \mathrm{ml}$, the effective area of membrane was $32.2 \mathrm{~cm}^{2}$, and the rotational speed of an internal magnetic stirrer was $300 \mathrm{rpm}$. The cell was immersed in a water bath kept at $30^{\circ} \mathrm{C}$. The operating pressure was $20 \mathrm{Kg} / \mathrm{cm}^{2} \cdot \mathrm{G}$. The feed concentration of amino acid in single aqueous solution was $1.0 \times 10^{-3} \mathrm{~mol} / l$. The mixed amino acids in binary aqueous solution were prepared by dissolving L-alanine $\left(1.0 \times 10^{-3} \mathrm{~mol} / l\right)$ and added amino acids $\left(2.5 \times 10^{-4}, 6.7 \times 10^{-4}, 1.5 \times 10^{-3}\right.$ and 4 . Ox $\left.10^{-3} \mathrm{~mol} / l\right)$ in deionized water. The sampling method was as follows: When the solution was in a single system, 6. Oml of permeate was collected as permeate sample after discarding initial 2. Oml of permeate. When the solution was in a binary system, $8.0 \mathrm{ml}$ of permeate was collected as permeate sample after discarding initial $8.0 \mathrm{ml}$ of permeate. Before the experiments on reverse osmosis separation of amino acid solutions, membranes were always tested with distilled water and 5000 ppm of sodium chloride aqueous solution, and the relation between pure water permeability A and rejection $\eta$ of sodium chloride was checked. 


\section{RESULTS AND DISCUSSION}

\section{Equation of transport}

Rejection $\eta(-)$ is defined as follows;

$$
\eta \equiv \frac{C_{2}-C_{3}}{C_{2}}
$$

where $C_{2}$ is concentration of solute at the membrane surface $\left(\mathrm{g}-\mathrm{mol} / \mathrm{cm}^{3}\right)$ and $C_{3}$ is concentration of solute in permeate $\left(\mathrm{g}-\mathrm{mol} / \mathrm{cm}^{3}\right)$. Generally, $C_{2}$ differs from concentration of solute in feed solution $C_{1}\left(\mathrm{~g}-\mathrm{mol} / \mathrm{cm}^{3}\right) . C_{2}$ is obtained from the following equation.

$$
C_{2}=C_{3}+\left(C_{1}-C_{3}\right) \exp \left[\frac{N_{w}+N_{s}}{c_{1} \cdot k}\right]
$$

where $N_{w}$ is molar flux of water $\left(\mathrm{g}-\mathrm{mol} / \mathrm{cm}^{2} \cdot \mathrm{sec}\right), N_{s}$ is molar flux of solute $\left(\mathrm{g}-\mathrm{mol} / \mathrm{cm}^{2} \cdot \mathrm{sec}\right), \quad c_{1}$ is molar density of feed solution $\left(\mathrm{g}-\mathrm{mol} / \mathrm{cm}^{3}\right)$, and $k$ is mass transfer coefficient $(\mathrm{cm} / \mathrm{sec})$. Mass transfer coefficient $k$ depends on the shape of cell and streaming state of solution in the cell. On the cell used in this study, k can be represented as follows;

$$
k=7.586\left(\frac{D}{l}\right) R e^{0.420} S c^{1 / 3}
$$

where $D$ is diffusivity $\left(\mathrm{cm}^{2} / \mathrm{sec}\right), l$ is inside diameter of cell $(\mathrm{cm})$. Re is Reynolds number $(-)$, and Sc is Schmidt number $(-)$. Solute transport parameter $D / K \delta$ is defined as follows;

$$
D / K \delta=\frac{N_{s}}{C_{2}-C_{3}}=\frac{J C_{3}}{C_{2}-C_{3}}=J\left(\frac{1}{\eta}-1\right)
$$

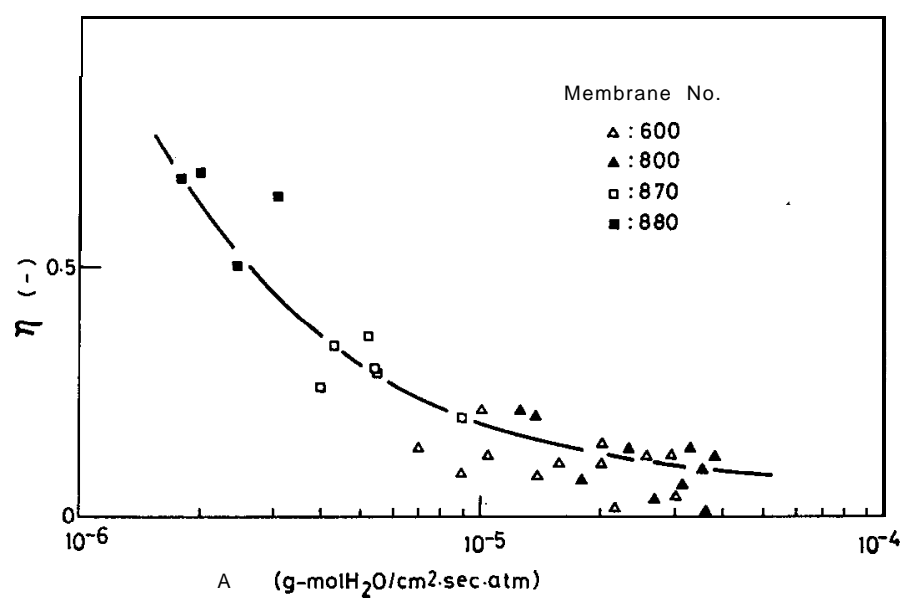

Fig. 1. Relation between $\eta$ and $A$ for 5000 ppm of $\mathrm{NaCl}$ aqueous solution. 
where $\boldsymbol{J}$ is volume flux of permeate $\left(\mathrm{cm}^{3} / \mathrm{cm}^{2} \cdot \mathrm{sec}\right)$.

$k$ for sodium chloride was $9.73 \times 10^{-3} \mathrm{~cm} / \mathrm{sec}$. Fig. 1 shows the relation between rejection $\eta$ of sodium chloride and pure water permeability A, which was obtained by using various DDS-cellulose acetate membranes.

2. Prediction of permeation of amino acid in single aqueous solution systems

Following equation is proposed for solute transport parameter $D / K \delta$ of nonionized polar aliphatic and alicyclic compounds (Matsuura et al., 1976, 1977).

$$
\ln (D / K \delta)=\ln C^{*}+\rho^{*} \Sigma \sigma^{*}+\delta^{*} \Sigma E_{s}+\omega^{*} \Sigma S^{*}
$$

where $1 n C^{*}$ is a constant depending on the porous structure of membrane surface, the chemical nature of membrane material, and the nature of functional group in solute molecule. $\rho^{*} \Sigma \sigma^{*}, \delta^{*} \Sigma E_{\mathrm{s}}$ and $\omega^{*} \Sigma S^{*}$ are polar effect, steric effect, and nonpolar effect, respectively. $\Sigma \sigma^{*}$ and $\Sigma E_{s}$ are Taft's polar and steric parameters, respectively, and $\Sigma S^{*}$ is nonpolar parameter (modified Small's number). $\rho^{*}, \delta^{*}$ and $\omega^{*}$ are the characteristic proportionality constants associated with $\Sigma \sigma^{*}, \Sigma E_{s}$ and $\Sigma S^{*}$, respectively. Though $\rho^{*}$ and $\omega^{*}$ don't depend on the porous structure of membrane surface, $\delta^{*}$ does. Physicochemical properties of some amino acids of aliphatic and aromatic types are shown in Table 1. The nonpolar effect $\omega^{*} \Sigma S^{*}$ may be considered negligible if the molecular structure of solute contains a straight chain involving no more than three carbon atoms not associated with a polar functional group. Therefore, following equation is applied to glycine and L-alanine.

$$
\ln (D / K \delta)=\ln C^{*}+\rho^{*} \Sigma \sigma^{*}+\delta^{*} \Sigma E_{s} .
$$

Both $\Sigma \sigma^{*}$ and $\Sigma E_{s}$ in L-alanine is zero. Therefore, $\ln C^{*}$ is as follows;

$$
\ln C^{*}=\ln (\boldsymbol{D} / \boldsymbol{K} \boldsymbol{\delta})_{\mathrm{L}-\text { alanine }} \text {. }
$$

From Eq. (6), $\boldsymbol{\delta}^{*}$ is as follows ;

$$
\delta^{*}=\frac{\ln (D / K \delta)-\ln C^{*}-\rho^{*} \Sigma \sigma^{*}}{\Sigma E_{s}}
$$

\begin{tabular}{|c|c|c|c|c|c|c|}
\hline $\begin{array}{c}\text { Solute } \\
\text { number }\end{array}$ & Amino acid & $\underset{\mathrm{R}-\mathrm{CH}\left(\mathrm{NH}_{2}\right) \mathrm{COOH}}{\mathrm{in}}$ & $\begin{array}{l}\Sigma E_{s} \\
(-)\end{array}$ & $\stackrel{\Sigma \sigma^{*}}{(-)}$ & $\left(\frac{\sqrt{\frac{\Sigma S^{*}}{\mathrm{cal} \cdot \mathrm{ml} l}}}{\mathrm{~g} \cdot \mathrm{mol}}\right)$ & $\begin{array}{c}k \times 10^{4} \\
(\mathrm{~cm} / \mathrm{sec})\end{array}$ \\
\hline \multirow{6}{*}{$\begin{array}{l}1 \\
2 \\
3 \\
4 \\
5 \\
6 \\
7 \\
8 \\
9\end{array}$} & Glycine L-alanine & $\mathrm{CH}$ & 0.001 .24 & 0.490 .0000 & 21490 & 78 \\
\hline & L-valine & $\left(\mathrm{CH}_{3}\right)_{2} \mathrm{CH}$ & -0.47 & -0.190 & 456 & $\begin{array}{l}70 \\
61\end{array}$ \\
\hline & L-isoleucine L-leucine & $\left(\mathrm{CH}_{3}\right)\left(\mathrm{C}_{3} \mathrm{H}_{5}\right) \mathrm{CH}$ & $-0.93 \cdot 1.13$ & $-0.125 \cdot 0.210$ & 58959 & 57 \\
\hline & DL-norvaline & $\left.\mathrm{CH}_{3} \mathrm{CH}_{2}\right)_{2}$ & -0.36 & -0.115 & 480 & 61 \\
\hline & DL-norleucine & $\mathrm{CH}_{3}\left(\mathrm{CH}_{2}\right)_{3}$ & $-0.39-2.55$ & -0.1300 .600 & 355613 & 57 \\
\hline & L-phenylalanine & $\stackrel{\mathrm{C}_{6}^{6} \mathrm{H}_{5}}{\mathrm{C}_{5}} \mathrm{CH}_{2}$ & -0.38 & 0.215 & 468 & $\begin{array}{l}57 \\
55\end{array}$ \\
\hline
\end{tabular}

Table 1. Summary of physicochemical properties of some amino acids. 
Reaction constant $(=1.465)$ in hydrolysis reaction of ester ( $\mathrm{R}^{\prime} \mathrm{COOR}, \mathrm{R}$ and R' are aliphatic substituent) (Taft, 1956) was employed as numerical value of $\rho^{*}$. Relation between $D / K S$ and pure water permeability $A$ for L-alanine and glycine is shown in Fig. 2. The values $\ln C^{*}$ and $\delta^{*}$ are plotted in Fig. 3, which are calculated from Eqs.(7), (8) and plot points in Fig. 2. Using the results described above, $\omega^{*}$ for some aliphatic and aromatic amino acids was calculated. Fig. 4 shows the relation between $\omega^{*}$ and A. As mentioned above, $\omega^{*}$ doesn't depend on porous structure of membrane surface, i.e., pure water permeability $\mathrm{A}$. The region of $\mathrm{A}$ about $6 \times 10^{-6}$ to $1 \times 10^{-5} \mathrm{~g}$-mol $\mathrm{H}_{2} \mathrm{O} / \mathrm{cm}^{2} \cdot \mathrm{sec} \cdot \mathrm{atm}$ is satisfied. In this region of A, Eq. (5) which is proposed

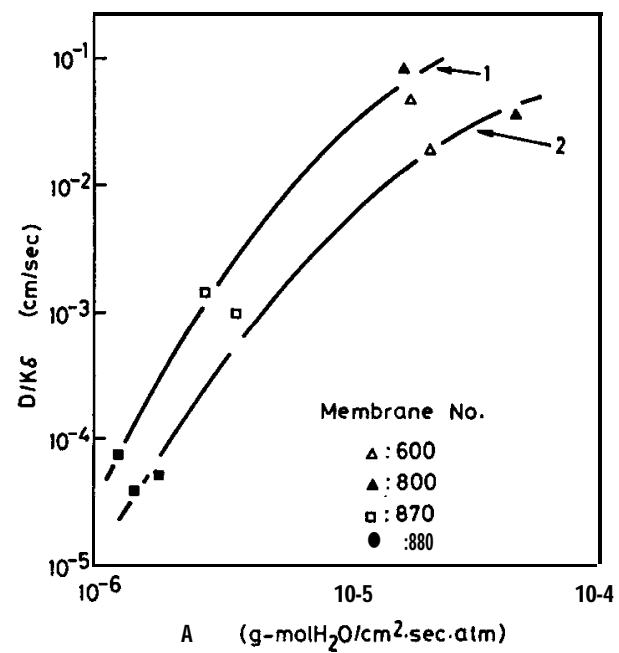

Fig. 2. Relation between $D / K \delta$ and $A$ for glycine and L-alanine aqueous solution. Amino acid; 1: glycine, 2: L-alanine.

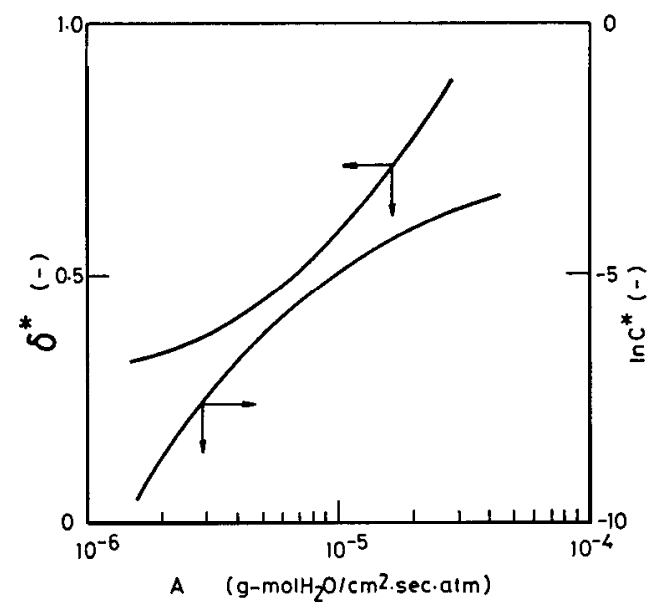

Fig. 3. Determination of $\ln \mathrm{C}^{*}$ and $\delta^{*}$. 


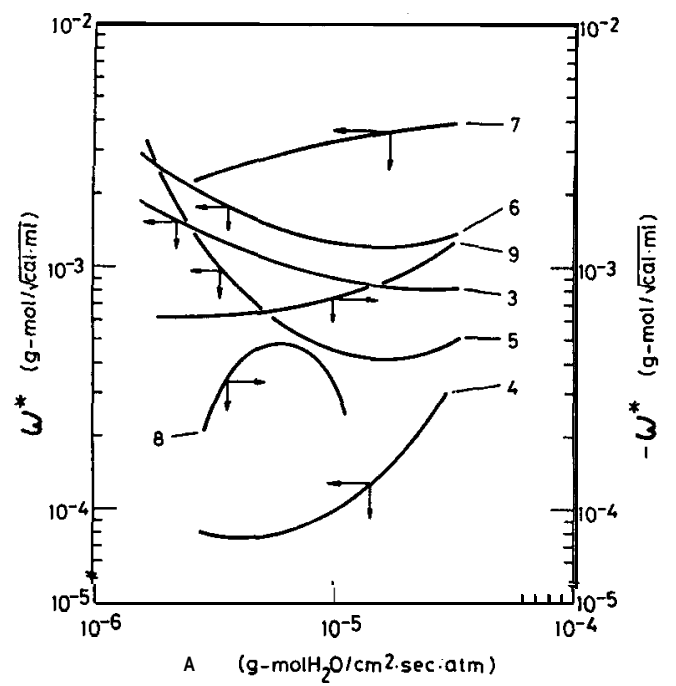

Fig. 4. Relation between $\omega^{*}$ and A. Number is solute number of amino acid.

for nonionized polar aliphatic and alicyclic organic compounds can be applied to some amino acids of aliphatic and aromatic types which are ionic solutes. Therefore, preferential permeability of monoamino monocarboxylic acids is discussed at $8 \times 10^{-6} \mathrm{~g}-\mathrm{molH}_{2} \mathrm{O} / \mathrm{cm}^{2} \cdot \mathrm{sec} \cdot$ atm of $\mathrm{A}$.

Though $\Sigma \sigma^{*}$ and $\Sigma E_{s}$ for variety of substituents are tabulated in Taft's table (Taft, 1956), the number of substituent listed is not so many. On the other hand, $\Sigma S^{*}$ is applied to substituents composed of hydrocarbon only (Matsuura and Sourirajan, 1973). Therefore, for the sake of application of Eq. (5) to sulfur containing, aromatic, and hydroxy amino acids, it is necessary to correlate characteristic parameters $\left(\Sigma \sigma^{*}, \Sigma E_{s}, \Sigma S^{*}\right)$ with other physical quantities, and to obtain characteristic parameters which can be applied to these amino acids on using the correlation obtained. First, covalent bond between diverse atoms contains some polarity $\alpha$ (Nomura, 1971). As polarity $\alpha$ was measured (Azumi, 1969), it is possible to calculate the proportion of ionic bond in an optional substituent (R). On the representing proportion of ionic bond (polarity of covalent bond) by $\boldsymbol{B}, \boldsymbol{B}$ was calculated in this study as follows ;

(ex. 1) L-serine $\left(\mathrm{R}=\mathrm{CH}_{2} \mathrm{OH}\right)$

$$
\mathrm{R}-\mathrm{C}: 2(\mathrm{C}-\mathrm{H})+(\mathrm{C}-\mathrm{O})+(\mathrm{O}-\mathrm{H})+(\mathrm{C}-\mathrm{C}) \text {. }
$$

Therefore,

$$
\boldsymbol{B}=(2 \times 0.06+0.125+0.31+0.0) / 5=0.111 .
$$

(ex. 2) L-tyrosine $\left(\mathrm{R}=\mathrm{HOC}_{6} \mathrm{H}_{4} \mathrm{CH}_{2}\right)$

$$
\mathrm{R}-\mathrm{C}=(\mathrm{O}-\mathrm{H})+7(\mathrm{C}-\mathrm{H})+8(\mathrm{C}-\mathrm{C}) .
$$


Therefore,

$$
B=(0.31+7 \times 0.06+8 \times 0.0) / 16=0.046 .
$$

Polar effect would be obtained in correlation with $B$. The relation between $\Sigma \sigma^{*}$ and $B$ is illustrated in Fig. 5. Four kinds of plot were obtained as follows ;

Plot (1): Substituents are constituted of aromatic ring and/or hydrocarbon.

Plot (2) : Substituents are constituted of aromatic ring and/or hydrocarbon and/or hydroxyl group and/or oxygen atom.

Plot (3) : Substituents are constituted of hydrocarbon.

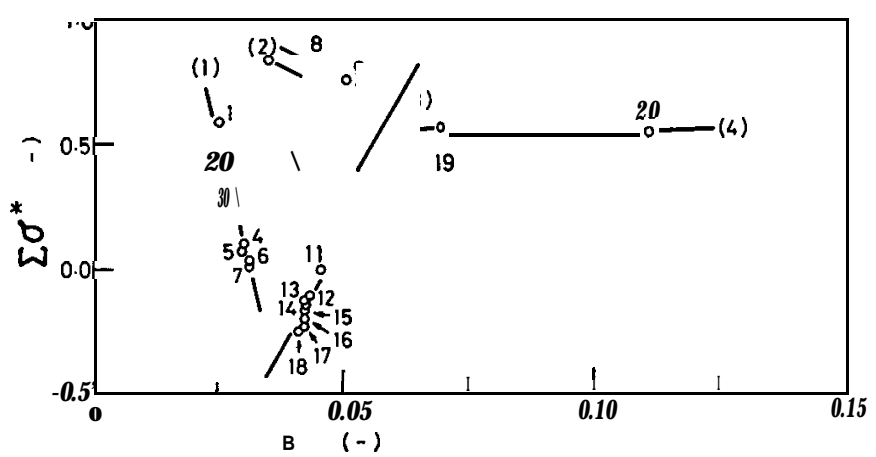

Fig. 5. Relation between Taft's polar parameter and polarity of covalent bond. $\mathrm{R}$ in $\mathrm{R}-\mathrm{Y}\left(\mathrm{R}\right.$ : Substituent, Y: Functional group) $; 1: \mathrm{C}_{6} \mathrm{H}_{5}, 2:\left(\mathrm{C}_{6} \mathrm{H}_{5}\right)_{2} \mathrm{CH}$, 3: $\mathrm{C}_{6} \mathrm{H}_{5} \mathrm{CH}_{2}, 4: \mathrm{C}_{6} \mathrm{H}_{5}\left(\mathrm{CH}_{3}\right) \mathrm{CH}$, 5: $\mathrm{C}_{6} \mathrm{H}_{5}\left(\mathrm{CH}_{2}\right)_{2}, 6: \mathrm{C}_{6} \mathrm{H}_{5}\left(\mathrm{C}_{2} \mathrm{H}_{5}\right) \mathrm{CH}, 7: \mathrm{C}_{6} \mathrm{H}_{5}\left(\mathrm{CH}_{2}\right)_{3}$, 8: $\mathrm{C}_{6} \mathrm{H}_{5} \mathrm{OCH}_{2}, 9: \mathrm{C}_{6} \mathrm{H}_{5}(\mathrm{OH}) \mathrm{CH}, 10: \mathrm{H}, 11: \mathrm{CH}, 12: \mathrm{n}-\mathrm{C}_{2} \mathrm{H}_{5}, 13: \mathrm{n}-\mathrm{C}_{3} \mathrm{H}_{7}, 14:$

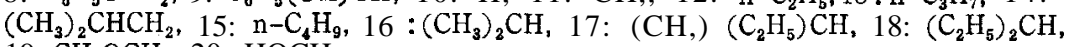
19: $\mathrm{CH}_{3} \mathrm{OCH}_{2}, 20$ : $\mathrm{HOCH}$,

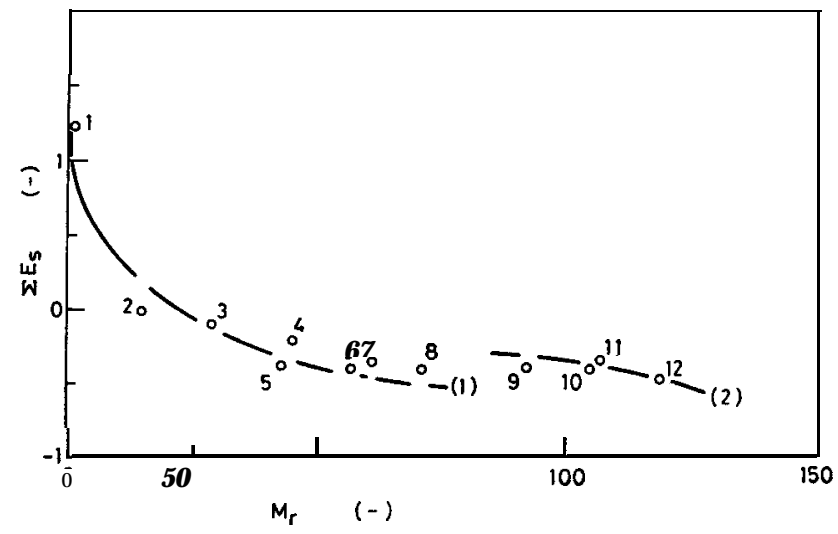

Fig. 6. Relation between Taft's steric parameter and molecular weight of substituent. Substituent; 1: H, 2: $\mathrm{CH}, 3: \mathrm{C}_{2} \mathrm{H}_{5}, 4: \mathrm{CH}_{3} \mathrm{OCH}_{2}, 5: \mathrm{n}-\mathrm{C}_{3} \mathrm{H}_{7}, 6$ : $n-\mathrm{C}_{4} \mathrm{H}_{9}, 7: \mathrm{CH}_{3} \mathrm{SCH}_{2}, 8: \mathrm{n}-\mathrm{C}_{5} \mathrm{H}_{11}$, 9: $\mathrm{C}_{6} \mathrm{H}_{5} \mathrm{CH}_{2}, 10: \mathrm{C}_{6} \mathrm{H}_{5}\left(\mathrm{CH}_{2}\right)_{2}, 11: \mathrm{C}_{6} \mathrm{H}_{5} \mathrm{OCH}$, $12: \mathrm{C}_{6} \mathrm{H}_{6}\left(\mathrm{CH}_{2}\right)_{3}$. 
Plot (4) : Substituents are constituted of hydrocarbon and/or hydroxyl group.

Next, as steric effect depends on the size and shape of solutes, it would be related to a molecular weight of substituent. Fig. 6 shows the relation between $\Sigma E_{s}$ and molecular weight of substituent $M_{r}$. In this case, two kinds of plot were obtained as follows;

Plot (1) : Substituents are constituted of hydrocarbon and/or sulfur atom and/or oxygen atom.

Plot (2) : Substituents are constituted of aromatic ring and/or hydrocarbon and/or oxygen atom.

On the other hand, nonpolar effect would be depended on the hydrophobic interaction energy between membrane and solute, which is represented by interaction energy of London-van der Waals dispersion force $E_{l}$ (erg) as follows (Chu, 1971) ;

$$
E_{l}=-\int_{V_{s}} d \tau_{s} \int_{V_{m}} d \tau_{m} \frac{n_{s} n_{m} \Lambda}{l_{o}^{6}}
$$

And, London-van der Waals constant $\boldsymbol{\Lambda}\left(\mathrm{erg} \cdot \mathrm{cm}^{6}\right)$ is represented as follows;

$$
\Lambda=\frac{3}{2} \cdot \frac{\alpha_{s} \alpha_{m} I_{s} I_{m}}{I_{s}+I_{m}}
$$

where $\Lambda$ is whole volume of substance considered $\left(\mathrm{cm}^{3}\right), d \tau$ is volume fraction of substance considered $\left(\mathrm{cm}^{3}\right), n$ is number of molecule contained in $1 \mathrm{~cm}^{3}$ of substance considered (number $/ \mathrm{cm}^{3}$ ), $l_{o}$ is intermolecular distance $(\mathrm{cm}), \alpha$ is polarizability $\left(\mathrm{cm}^{3}\right)$, and $I$ is ionization potential (erg). Subscripts $s$ and $m$ refer to solute and membrane, respectively. The cylindrical pore model for skin layer of cellulose acetate membrane is shown in Fig. 7. Pore radius $r_{1}$ of membrane whose pure water permeability A and rejection of sodium chloride are $8 \times 10^{-6}$ and 0.21 , respectively was calculated by the use of C. P. Bean Equation (Bean, 1969) as follows;

$$
r_{1}=1 \times 10^{-6}(\mathrm{~cm}) .
$$

Now, the hydrophobic interaction would be taken place between a single solute molecule existing at the center of cylindrical pore (inside diameter $=r_{1}$, outside diameter $=r_{2}$, length $=2 Z_{o}$ ) and methyl groups in cellulose acetate is assumed. Change in hydrophobic interaction energy $\boldsymbol{A} \boldsymbol{E}$, which takes place when a single solute molecule moves from bulk phase to center of pore is as follows;

$$
\Delta E_{l}=\left(E_{l}\right)_{\text {pore }}-\left(E_{l}\right)_{\text {buls }} \text {. }
$$

In bulk phase, the distance between a solute molecule and methyl group is long enough. Therefore, we obtain

$$
\left(E_{l}\right)_{\text {bulk }}=0 \text {. }
$$

From Eqs.(9),(12),(13), following equation is obtained. 


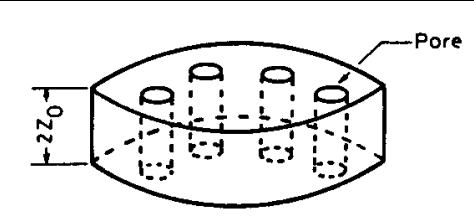

(a) Skin layer of membrane

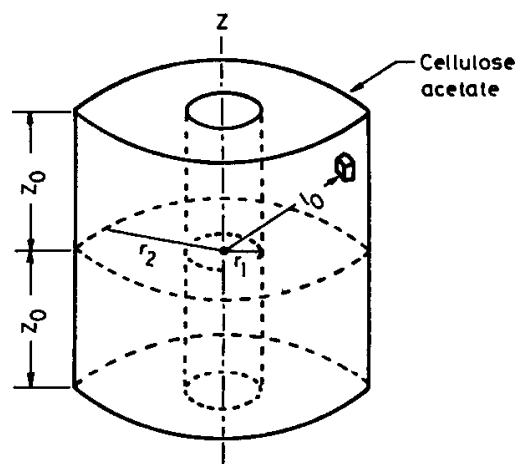

(b) Pore

Fig. 7. Schematic representation of cellulose acetate membrane.

$$
\Delta E_{l}=-\left(\int_{V_{s}} d \tau_{s} \int_{V_{m}} d \tau_{m} \frac{n_{s} n_{m} \Lambda}{l_{o}^{6}}\right)_{\text {pore }}
$$

Here, following assumption is set up.

$$
Z_{o}, r_{2}=\infty \text {. }
$$

As solute considered is a single molecule, we obtain

$$
\int_{v_{s}} d \tau_{s}(n,)=1
$$

Also,

$$
\begin{aligned}
& \Delta \tau_{m}=r \Delta \theta \Delta r \Delta Z \\
& l_{o}=\left(r^{2}+Z^{2}\right)^{1 / 2} .
\end{aligned}
$$

From Eqs. (14) $\sim(18)$, following equation is obtained.

$$
\Delta E_{l}=\lim , \ldots, \mathrm{n}_{\rightarrow \infty}\left[-\Lambda n_{m} \int_{0}^{2 \pi} d \theta \int_{-z_{0}}^{z_{0}}\left[\int_{r_{1}}^{r_{2}} \frac{r d r}{\left(r^{2}+Z^{2}\right)^{1 / 2}}\right] d z\right]=-\frac{\pi^{2} \Lambda n_{m}}{4 r_{1}^{3}} .
$$

DDS-cellulose acetate membrane is taken as 2.5 cellulose acetate membrane. The molecular weight $M$ of pentaacetyl-cellobiose which is a repeating unit of 2.5 cellulose acetate is 534 . The density $\rho$ of cellulose acetate is $1.30(\mathrm{~g} /$ 
$\mathrm{cm}^{3}$ ). If a methylene is regarded as methyl group, the number of methyl group contained in a pentaacetyl-cellobiose is seven. Therefore, the number of methyl group contained in $1 \mathrm{~cm}^{3}$ of 2.5 cellulose acetate $\boldsymbol{n}_{m}$ is calculated as follows ;

$$
\mathrm{n},=(7)\left(\frac{\rho}{M}\right) N=1.03 \times 10^{22}\left(\text { number } / \mathrm{cm}^{3}\right)
$$

where $\mathrm{N}$ is avogadro number.

Substituting Eqs.(10), (11) and (20) in Eq.(19) gives the following equation.

$$
\Delta E_{l}=-\left(3.81 \times 10^{40}\right) \frac{\alpha_{s} \alpha_{m} I_{s} I_{m}}{I_{s}}(\mathrm{erg}) .
$$

a, is calculated by using following equation.

$$
\alpha_{s}=\frac{3[R]}{4 \pi N}
$$

where [R] is molecular refraction. Ionization potential of an organic compound which is made by adding a single hydrogen atom to the substituent of amino acid was employed for that of amino acid. Polarizability $\alpha_{s}$ and ionization potential $I_{s}$ of some amino acids of aliphatic and aromatic types are shown in Table 2. On the other hand, polarizability of methyl group $\alpha_{m}$ is $2.71 \mathrm{X}$ $10^{-24}\left(\mathrm{~cm}^{\prime \prime}\right)$. Taking methyl group as methane, ionization potential of methyl group $I_{m}$ is $2.09 \times 10^{-11}$ (erg). By inserting numerical values to Eq.(21), the relation between hydrophobic interaction energy $\boldsymbol{A} \boldsymbol{E}$, and nonpolar parameter $\boldsymbol{\Sigma} \boldsymbol{S}^{*}$ is obtained, as shown in Fig. 8. Two kinds of plot were obtained a s follows ;

Plot (1) : Substituents haven't aromatic ring.

Plot (2) : Substituents have aromatic ring.

Polarity of covalent bond $\boldsymbol{B}$, molecular weight of substituent $M_{r}$ and interaction energy of London-van der Waals dispersion force $\boldsymbol{A} \boldsymbol{E}$, of each amino acids, which were calculated by equations mentioned above were shown in Table 3. Taft's polar parameter $\Sigma \sigma^{*}$, Taft's steric parameter $\Sigma E_{s}$ and nonpolar parameter $\Sigma S^{*}$ which are applied to amino acids of hydroxy-substituted, aromatic, and sulfur-containing types were obtained by use of numerical

Table 2. Polarizability and ionization potential.

\begin{tabular}{clcc}
\cline { 2 - 3 } Solute number & \multicolumn{1}{c}{ Amino acid } & $\begin{array}{c}\alpha_{\mathbf{s}} \times 10^{24} \\
\left(\mathrm{~cm}^{\mathbf{3}}\right)\end{array}$ & $\begin{array}{c}I_{s} \times 10^{11} \\
(\mathrm{erg})\end{array}$ \\
\hline 2 & $\begin{array}{l}\text { L-alanine } \\
\text { L-valine }\end{array}$ & 9.65 & 2.09 \\
4 & $\begin{array}{l}\text { L-leucine } \\
5\end{array}$ & 15.26 & 1.73 \\
6 & L-isoleucine DL-norvaline & $\overline{8}$ \\
7 & DL-norleucine D-phenylglycine & 13.39 & 1.80 \\
8 & L-phenylalanine & 17.4615 .26 & 1.511 .73 \\
9 & $\beta-$-methyl- $\beta$-phenylalanine & 19.33 & 1.48 \\
11 & & 11.5221 .13 & 1.881 .46 \\
\hline
\end{tabular}




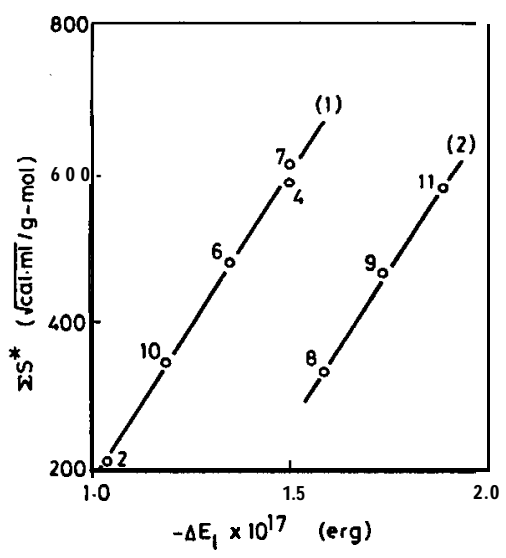

Fig. 8. Relation between nonpolar parameter and interaction energy of London-van der Waals dispersion force. Number is solute number of amino acid.

values in Table 3 and the correlations shown in Figs. 5, 6 and 8, and are shown in Table 4. The number in parenthesis shown in Table 4 is a plot number in Figs. 5, 6 and 8. In calculating of Taft's polar parameter, sulfur atom were taken as carbon atom, because electronegativity of sulfur atom is the same as that of carbon atom. Characteristic proportionality constant as-

Table 3. Summary of physicochemical properties.

\begin{tabular}{|c|c|c|c|c|c|c|c|c|}
\hline $\begin{array}{l}\text { Solute } \\
\text { number }\end{array}$ & Amino acid & $\begin{array}{c}\mathrm{R} \quad \text { in } \\
\mathrm{R}-\mathrm{CH}\left(\mathrm{NH}_{2}\right) \\
\mathrm{COOH}\end{array}$ & $\begin{array}{c}M_{r} \\
(-)\end{array}$ & $\begin{array}{c}B \\
(-) \\
\end{array}$ & $\begin{array}{c}\alpha_{s} \times 10^{24} I \\
(\mathrm{~cm} ")\end{array}$ & $\begin{array}{c}I_{s} \times 10^{\prime \prime} \\
(\mathrm{erg})\end{array}$ & $\begin{array}{r}\Delta E_{l} \times 10^{17} \\
(\mathrm{e} \mathrm{r} \mathrm{g})\end{array}$ & $\begin{array}{c}k \times 10^{4} \\
(\mathrm{~cm} / \mathrm{sec})\end{array}$ \\
\hline 12 & & & & & & & & 67 \\
\hline 13 & L-threonine L-serine & $\mathrm{CH}_{3} \mathrm{CH}(\mathrm{OH})$ & 45.0831 .35 & 0.0840 .111 & 12.1710 .37 & 1.701 .75 & 1.02 & 62 \\
\hline 14 & L-homoserine & $\mathrm{HO}\left(\mathrm{CH}_{2}\right)_{2}$ & 45.08 & 0.084 & 12. & 1.70 & -1 & \\
\hline 16 & Doparosine & $(\mathrm{OH})_{2} \mathrm{C}_{6} \mathrm{H}_{3} \mathrm{CH}_{2}$ & 107.15123 .15 & 0.0460 .061 & 20.4619 .94 & 1.441 .44 & $-1.75-1.80$ & 5352 \\
\hline $\begin{array}{l}18 \\
19\end{array}$ & L-cysteine L-methionine & $\mathrm{CH}_{3} \mathrm{~S}\left(\mathrm{CH}_{2}\right)_{2}$ & 75.1747 .12 & 0.0380 .035 & 16.4812 .86 & 1.511 .51 & $-1.16-1.49$ & $\begin{array}{l}57 \\
59\end{array}$ \\
\hline 20 & DL-ethionine DL-homocysteine & $\mathrm{C}_{2} \mathrm{H}_{5} \mathrm{~S}\left(\mathrm{CH}_{2}\right)_{2}$ & 89.0961 .12 & 0.0360 .039 & 14.7318 .35 & 1.481 .51 & $-1.32-1.66$ & 54 \\
\hline
\end{tabular}

Table 4. Characteristic parameters.

\begin{tabular}{lccc}
\hline \multicolumn{1}{c}{ Amino acid } & $\begin{array}{c}\Sigma \sigma^{*} \\
(-)\end{array}$ & $\begin{array}{c}\Sigma E_{s} \\
(-)\end{array}$ & $\left(\frac{\Sigma S^{*}}{\mathrm{cal} \cdot \mathrm{ml}}\right)$ \\
\hline L-sol & & $203(1)$ \\
L-thrine & $0.555(4)$ & $-0.18(1)$ & $340(1)$ \\
L-homonine & $0.530(4)$ & $-0.30(1)$ & $340(1)$ \\
L-tyrosine & $0.530(4)$ & $-0.30(1)$ & $479(2)$ \\
Dopa & $0: 800(2)$ & $-0.38(2)$ & $521(2)$ \\
L-cysteine & $0.600(2)$ & $-0.46(2)$ & $323(1)$ \\
L-methionine & $-0.400(3)$ & $-0.32(1)$ & $604(1)$ \\
DL-homocysteine & $-0.290(3)$ & $-0.46(1)$ & $459(1)$ \\
DL-ethionine & $-0.360(3)$ & $-0.40(1)$ & $748(1)$ \\
\hline
\end{tabular}


sociated with $\Sigma S^{*} \omega^{*}$ is represented from Eq.(5) as follows;

$$
\omega^{*}=\frac{\ln (D / K \delta)-\ln C^{*}-\rho^{*} \Sigma \sigma^{*}-\delta^{*} \Sigma E_{s}}{\Sigma S^{*}} .
$$

Fig. 9 shows the correlation between $\omega^{*}$ calculated by Eq. (23) and number of carbon atom in substituent (R). As a result, $\omega^{*}$ of aliphatic amino acids having straight substituent and hydroxy amino acids varies as the number of carbon atom, but $\omega^{*}$ of aliphatic amino acids having branched substituent, sulfur-containing amino acids, and aromatic amino acids varies inversely as the number of carbon atom. These relations were approximated by a first-order equation as follows :

For former,

$$
\omega^{*} \times 10^{5}=-544.7+(214.6) \text { (number of carbon atom). }
$$

For latter,

$$
\omega^{*} \times 10^{5}=243.1-(52.05) \text { (number of carbon atom). }
$$

By using these approximate equations, calculated value of rejection of each amino acids were obtained, and compared with that observed, as shown in Fig. 10. Calculated value of rejection agrees with observed value approximately.

On the other hand, Matsuura and Sourirajan (1974) propose the next equation for the solute transport parameter $D / K \delta$ of $\alpha$ type of monoamino monocarboxylic acid.

$$
\ln (D / K \delta)=\ln C^{*}+\rho^{*} p K_{1}+\delta^{*} \Sigma E_{3}
$$

where $p K_{1}$ is equilibrium constant. Amino acids for that Eq. (26) can be ap.

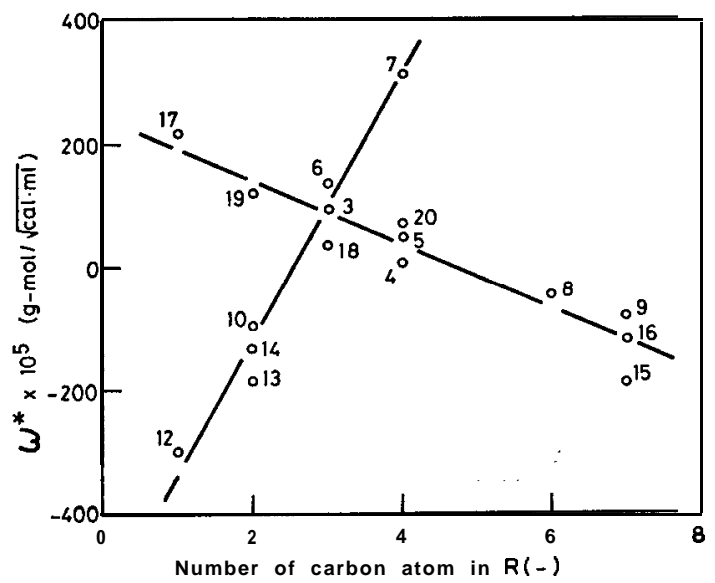

Fig. 9. Relation between $\omega^{*}$ and number of carbon atom in R. A: $8 \times 10^{-6}$ $\mathrm{g}-\mathrm{molH}_{2} \mathrm{O} / \mathrm{cm}^{2} \cdot \mathrm{sec} \cdot \mathrm{atm}$. Number is solute number of amino acid. 


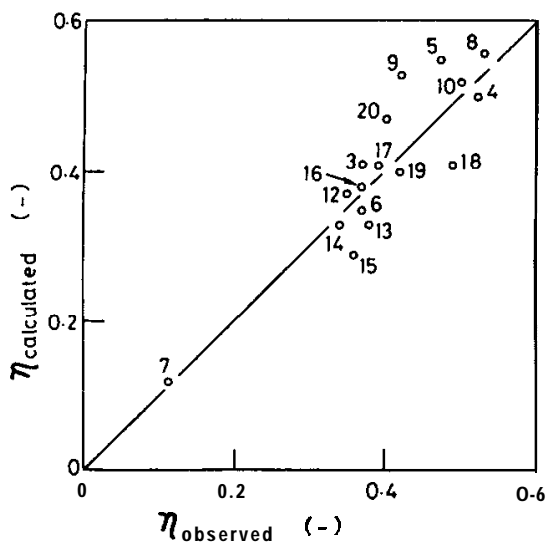

Fig. 10. Calculation of rejection of amino acid. A: $8 \times 10^{-6} \mathrm{~g}-\mathrm{molH}_{2} \mathrm{O} / \mathrm{cm}^{2}$. sec-atm. Number is solute number of amino acid.

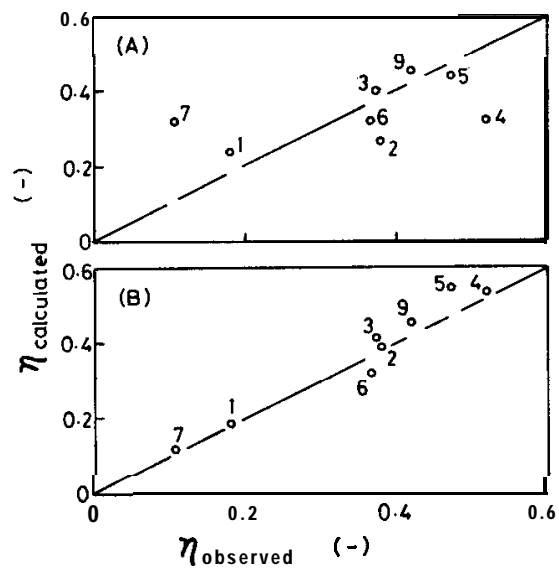

Fig. 11. Calculation of rejection of amino acid. \#observed is author's data. (A): $\eta_{\text {calculated }}$ was calculated by Eq.(26). (B) $: \eta_{\text {calculated }}$ was calculated by Eq.(5). A : $8 \times 10^{-6} \mathrm{~g}-\mathrm{molH}_{2} \mathrm{O} / \mathrm{cm}^{2} \cdot \mathrm{sec} \cdot \mathrm{atm}$. Number is solute number of amino acid.

plied are aliphatic amino acids only because of the calculation method of $\boldsymbol{B E}$, . Fig. 11 shows the comparison of the observed value of rejection obtained by authors with the calculated value of rejection obtained from Eq.(5) proposed by authors and with that obtained from Eq.(26), and indicates that Eq. (5) can predict rejection of amino acids more exactly than Eq. (26). Next, the observed values of rejection obtained by Matsuura and Sourirajan(1974) were analyzed by author's method mentioned above. As a result, the relation between $\omega^{*}$ and number of carbon atom in $\mathrm{R}$ was obtained, and shown in Fig. 12. This correlation obtained is consistent with that obtained by authors (ref. Fig. 9). Therefore, Eq.(5) is superior to Eq.(26) in the accuracy of a predic- 


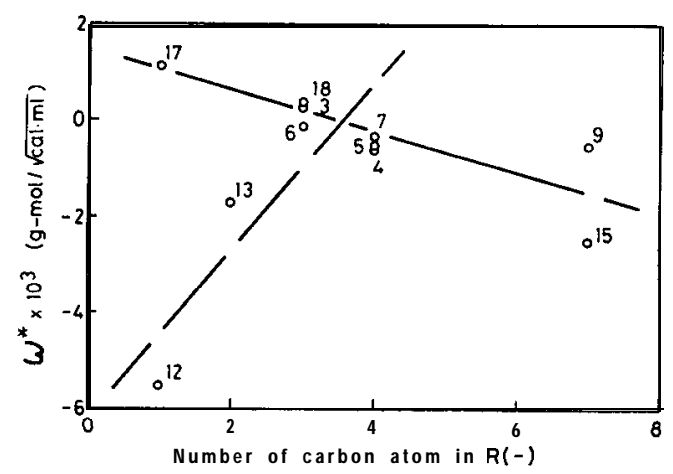

Fig. 12. Relation between $\omega^{*}$ and number of carbon atom in R. Data : Matsuura et al. (1974)'s data (Film No. 6). Number is solute number of amino acid.

tion of rejection and in the region of application for various series of amino acids.

3. Interaction between diverse amino acids on membrane-solution interface in binary aqueous solution systems

The reverse osmosis separation of fourteen kinds of solutions consisting of L-alanine $\left(1.0 \times 10^{-3} \mathrm{~mol} / l\right)$ and added amino acids $\left(2.5 \times 10^{-4} \sim 4.0 \times 10^{-3} \mathrm{~mol} / l\right)$ of aliphatic, hydroxy-substituted, sulfur-containing, and aromatic types was carried out. As a result, rejection of L-alanine was almost constant in the concentration range of the added amino acids (ca. 1 . Ox $10^{-3} \sim 4.0 \times 10^{-3} \mathrm{~mol} / \mathrm{l}$ ) in every respect of the system. But in certain system the rejection of L-alanine considerably increased at the concentration of the added amino acids (2.5 $\left.\times 10^{-4} \mathrm{~mol} / l\right)$. On the other hand, the rejection of added amino acids was almost constant in the total concentration range of the added amino acids (2.5 $\left.10^{-4} \sim 4.0 \times 10^{-3} \mathrm{~mol} / l\right)$ in most of the systems. Also, in single system the rejection of amino acids was almost constant in the concentration range $1.0 \times 10^{-3}$ to 4 . Ox $10^{-3} \mathrm{~mol} / l$, but decreased below at the conc. 1 . Ox $10^{-3} \mathrm{~mol} / l$, as shown in Fig. 13. Fig. 14 is a schematic diagram showing the amino acid separation as mentioned above. In order to investigate the interaction between L-alanine and added amino acid on the membrane-solution interface, four physical quantities were defined as follows;

$$
\begin{aligned}
& \Delta \eta_{1} \equiv \eta_{a}-\eta_{b} \\
& \Delta \eta_{2} \equiv \frac{\eta_{c}+\eta_{d}}{2}-\eta_{e} \\
& \Delta \eta_{3} \equiv \eta_{f}-\eta_{g} \\
& \Delta \eta_{4} \equiv \frac{\eta_{h}+\eta_{i}}{2}-\frac{\eta_{j}+\eta_{k}}{2}
\end{aligned}
$$




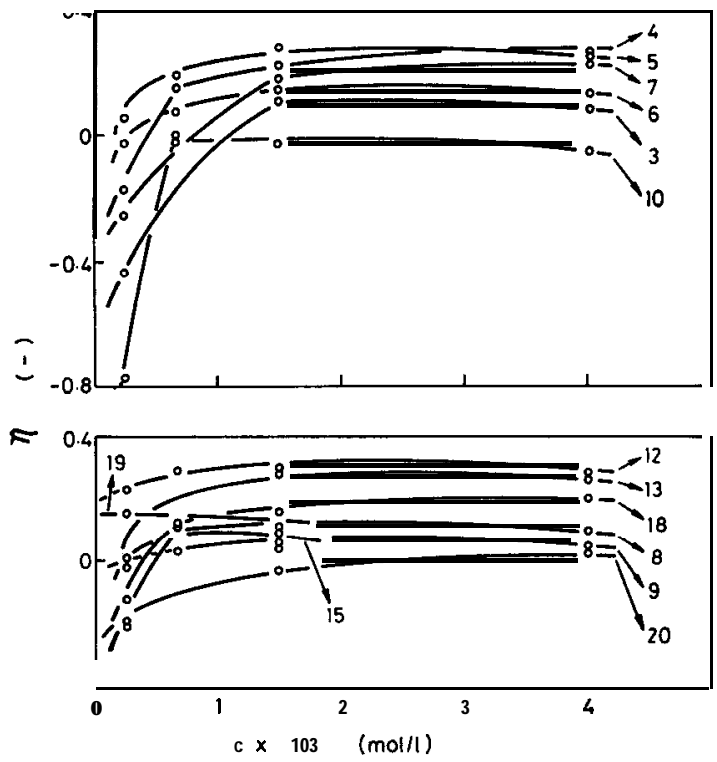

Fig. 13. Effect of concentration on rejection for single system. A: $8 \times 10^{-6}$ $\mathrm{g}-\mathrm{molH}_{2} \mathrm{O} / \mathrm{cm}^{2} \cdot \mathrm{sec} \cdot \mathrm{atm}$. Number is solute number of amino acid.

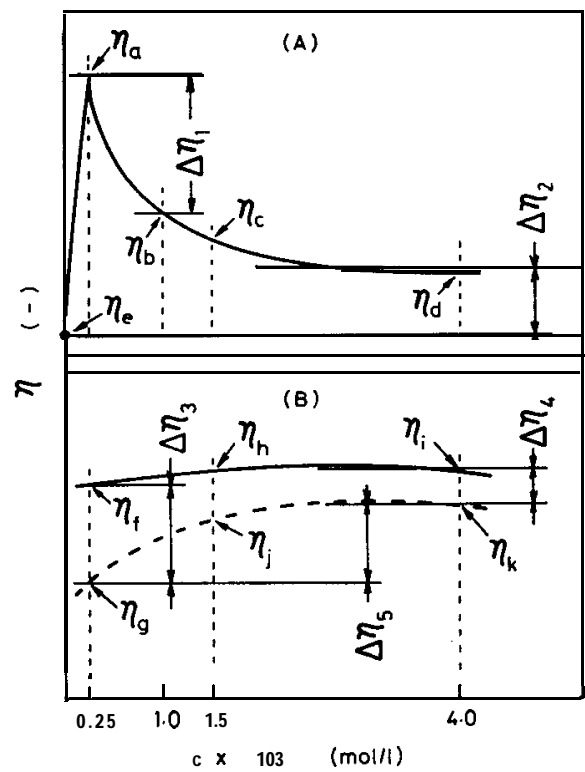

Fig. 14. Schematic representation of solute separation. (A) : L-alanine, (B): Added amino acid. Solid line: Binary system, broken line : Single system. 
Table 5. Difference between amino acid rejection in binary and single systems.

\begin{tabular}{|c|c|c|c|c|}
\hline Added amino acid & $\stackrel{\Delta \eta_{1}}{\longrightarrow}$ & $\stackrel{\Delta \eta_{2}}{(-)}$ & $\left.\stackrel{\Delta \eta_{3}}{(}\right)$ & $\stackrel{\Delta \eta_{4}}{(-)}$ \\
\hline L-serine & 0.02 & 0.10 & 0.15 & 0.15 \\
\hline L-threonine & 0.08 & 0.11 & 0.09 & -0.09 \\
\hline DL-2-aminobutyric alcid & 0.21 & 0.11 & 0.89 & 0.05 \\
\hline DL-norleucine & 0.52 & 0.23 & 0.46 & 0.00 \\
\hline DL-norvaline & 0.26 & 0.03 & -0.17 & 0.15 \\
\hline L-leucine & 0.30 & 0.23 & 0.44 & 0.03 \\
\hline L-valine & 0.34 & 0.11 & 0.90 & 0.21 \\
\hline L-isoleucine & 0.16 & 0.06 & 0.08 & -0.11 \\
\hline L-methionine & 0.03 & 0.21 & 0.35 & 0.02 \\
\hline DL-ethionine & 0.06 & 0.27 & 0.48 & 0.28 \\
\hline DL-homocysteine & 0.04 & 0.35 & & \\
\hline L-phenylalanine & 0.09 & 0.09 & 0.12 & $0 . \overline{14}$ \\
\hline D-phenylglycine & 0.02 & 0.10 & 0.14 & -0.12 \\
\hline L-tyrosine & 0.14 & 0.00 & 0.13 & 0.24 \\
\hline
\end{tabular}

where $\eta_{a}, \eta_{b}, \cdots \cdots \eta_{j}$ and $\eta_{k}$ are shown in Fig. 14. $\Delta \eta_{1}, \Delta \eta_{2}, \Delta \eta_{3}$ and $\Delta \eta_{4}$ in each system are tabulated in Table 5. $\Delta \eta_{1}, \Delta \eta_{2}, \Delta \eta_{3}$ and $\Delta \eta_{4}$ are positive in most of the system. Therefore, the rejection of both L-alanine and added amino acids is higher in a binary system than that in a single system. On the other hand, $\Delta \eta_{1}$ is greater in systems consisting of L-alanine and aliphatic amino acid than that in other systems. A cellulose acetate membrane is negatively charged slightly and basic. $\Delta \eta_{1}$ was correlated with Taft's polar parameter $\Sigma \sigma^{*}$ of each added amino acids, as shown in Fig. 15. As a result, when Taft's polar parameter of the added amino acid and that of L-alanine are close to each other, the rejection of L-alanine increases considerably, but when they are apart, the rejection of L-alanine is almost constant. On the other hand, the rejection of some amino acids especially such as aliphatic amino acids becomes positive to negative as the concentration of

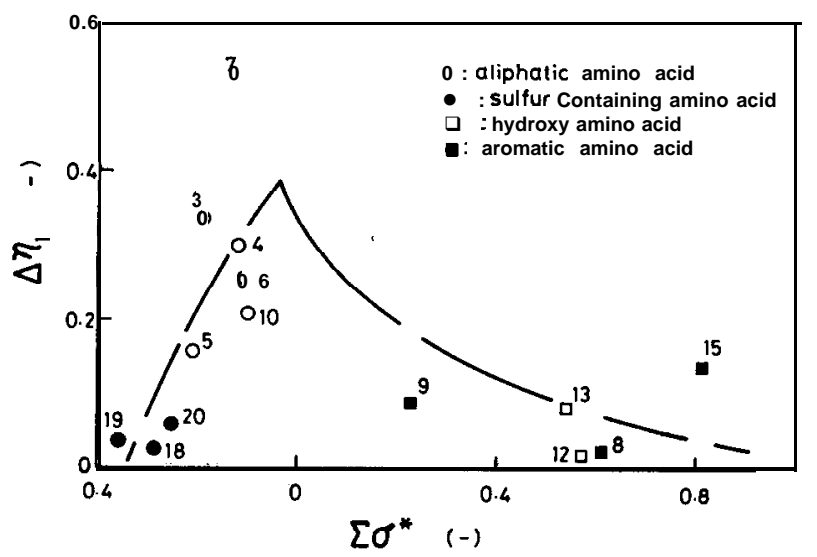

Fig. 15. Effect of Taft's polar parameter on $\Delta \eta_{1}$. A: $8 \times 10^{-6} \mathbf{g}-\mathrm{molH}_{2} \mathrm{O} /$ $\mathrm{cm}^{2} \cdot \mathrm{sec} \cdot \mathrm{atm}$. Number is solute number of amino acid. 
feed solution decreases from $1.0 \times 10^{-3}$ to $2.5 \times 10^{-4} \mathrm{~mol} / l$ in single aqueous solutions, as shown in Fig. 13. This typical behavior was considered to be due to the surface flow of amino acids on the basis of the formation of adsorbed layer of amino acids on a surface of the membrane near the concentration of the feed solution $\left(2.5 \times 10^{-4} \mathrm{~mol} / l\right)$. Based on the assumption mentioned above, the relation between $\Delta \eta_{1}$ and $\Sigma \sigma^{*}$ of added amino acids shown in Fig. 15 is explained. In the first place, in systems consisting of L-alanine and aliphatic aminoacids, L-alanine interacts with an adsorbed layer of aliphatic amino acids near the concentration of added amino acid $\left(2.5 \times 10^{-4} \mathrm{~mol} / l\right)$. But L-alanine hasn't strong affinity for the adsorbed layer of aliphatic amino acids because Taft's polar parameter $\Sigma \sigma^{*}$ of aliphatic amino acid and that of L-alanine are close to each other, i.e., acidity of aliphatic amino acid is equal to that of Lalanine approximately. Therefore, the rejection of L-alanine increases at the concentration of the added amino acids $\left(2.5 \sim 10^{-4} \mathrm{~mol} / l\right)$. Next, in systems consisting of L-alanine and added amino acids of hydroxy-substituted, sulfurcontaining and aromatic types, the adsorption layer of added amino acids is formed near the concentration of added amino acid $\left(2.5 \times 10^{-4} \mathrm{~mol} / l\right)$, however, its thickness seems to be thinner compared to that of aliphatic amino acids according to Fig. 13. Furthermore, L-alanine has strong affinity for the adsorbed layer of added amino acids because Taft's polar parameter of added amino acid and that of L-alanine are apart. Therefore, the rejection of L-alanine doesn't increase so much at the concentration of the added amino acids (2.5 $10^{-4} \mathrm{~mol} / \mathrm{l}$.

\section{REFERENCES}

Azumi, H. 1969 Ryoshi Kagaku. Baifukan, Tokyo, pp. 116

Bean, C. P. 1969 Research and Development Progress Report No. 465. Office of Saline Water, U. S. Department of the Interior, Washington, D. C.. pp. 30

Chu, B. 1971 Bunshi Kan Ryoku. Transl. by T. Iijima and H. Uedaira, Baifukan, Tokyo, PP. 49

Glueckauf, E. 1967 In "Proceedings of the First International Symposium on Water Desalination, Oct. 3-9, 1965," Vol. 1, Office of Saline Water, U. S. Department of the Interior, Washington, D. C.. pp. 143-156

Kedem, 0. and A. Katchalsky 1958 Thermodynamic analysis of the permeability of biological membranes to non-electrolytes. Biochem. Biophys. Acta, 27: 229-246

Lonsdale, H. K., B. P. Cross, F. M. Graber and C. E. Milstead 1971 Permeability of cellulose acetate membranes to selected solutes. J.Macromol. Sci.-Phys., 5B: 167-188

Lonsdale, H. K., U. Merten and R. L. Riley 1965 Transport properties of cellulose acetate osmotic membranes. J.Appl.Polym. Sci., 9: 1341-1362

Matsuura, T., A. C. Baxter and S. Sourirajan 1977 Predictability of reverse osmosis separations of higher alcohols in dilute aqueous solutions using porous cellulose acetate membranes. Ind. Eng. Chem. Process Des. Dev., 16(1) : 82-89

Matsuura, T., J. M. Dickson and S. Sourirajan 1976 Free energy parameters for reverse osmosis separations of undissociated polar organic solutes in dilute aqueous solutions. Ind. Eng. Chem. Process Des. Dev., 15(1) : 149-161

Matsuura, T. and S. Sourirajan 1973 Reverse osmosis separation of hydrocarbon in aque- 
ous solutions using porous cellulose acetate membranes. J.Appl.Polym.Sci., 17: 36833708

Matsuura, T. and S. Sourirajan 1974 Reverse osmosis separation of amino acids in aqueous solutions using porous cellulose acetate membranes. J.Appl.Polym. Sci., 18: $3593-$ 3620

Nomura, Y. 1971 Yuki Kagaku Taiyo. Yokendo, Tokyo, pp. 7

Taft, R. W., Jr. 1956 Separation of polar, steric, and resonance effects in reactivity. In "Steric Effects in Organic Chemistry," ed. by M. S. Newman, John Wiley \& Sons, Inc., New York, pp. 598, 608, 619 